\title{
Steviol effect, a glycoside of Stevia rebaudiana, on glucose clearances in rats
}

\author{
Melis, MS., Rocha, ST. and Augusto, A.* \\ Departamento de Biologia, Faculdade de Filosofia, Ciências e Letras de Ribeirão Preto - FFCLRP, \\ Universidade de São Paulo - USP \\ Av. Bandeirantes, 3900, CEP 14030-000, Ribeirão Preto, SP, Brazil \\ *e-mail: aaugusto@usp.br \\ Received June 25, 2007 - Accepted November 29, 2007 - Distributed May 31, 2009
}

\begin{abstract}
Stevia rebaudiana, a South American plant normally used as a natural herbal sweetener, has been suggested as exerting beneficial effects on human health, including as an antihypertensive and antihyperglycemic. The present experiment was undertaken to evaluate the renal excretion of steviol, the aglycone of several natural products extracted from the leaves of $S$. rebaudiana, and to clarify the actual participation of this compound on the renal excretion of glucose in rats, which has been previously suggested as the preferential action of steviol on the $\mathrm{Na}^{+}$-glucose renal tubular transport system. Steviol was obtained by enzymatic hydrolysis of stevioside with pectinase. Thirty normal male Wistar rats weighing $345 \mathrm{~g}$ were used. After a control period, steviol was infused $i v$ at three doses $(0.5,1.0$ and $3.0 \mathrm{mg} . \mathrm{kg}^{-1} / \mathrm{h}$ ), according to classical clearance techniques. During all the experiments no significant changes in inulin clearance $\left(\mathrm{C}_{\text {in }}\right)$ and $p$-aminohipuric acid clearance $\left(\mathrm{C}_{\mathrm{PAH}}\right)$ were observed. Administration of steviol resulted in a statistically significant increase in the fractional sodium excretion $\left(\mathrm{FeNa}^{+}\right)$, fractional potassium excretion $\left(\mathrm{FeK} \mathrm{K}^{+}\right)$, urinary flow as percent of glomerular filtration rate $(\mathrm{V} / \mathrm{GFR})$ and glucose clearance $\left(\mathrm{C}_{\mathrm{G}}\right)$ when compared to controls, but these effects were absent with the dose of $0.5 \mathrm{mg} \cdot \mathrm{kg}^{-1} / \mathrm{h}$. The steviol clearance $\left(\mathrm{C}_{\mathrm{S}}\right)$ was higher than the $\mathrm{C}_{\text {in }}$ and lower than the $\mathrm{C}_{\mathrm{PAH}}$ at all the doses employed in this study. The data suggest that steviol is secreted by renal tubular epithelium, causing diuresis, natriuresis, kaliuresis and a fall in renal tubular reabsorption of glucose.
\end{abstract}

Keywords: renal function, Stevia rebaudiana, steviol, renal excretion of glucose.

\section{O efeito do esteviol, um glicosídeo da Stevia rebaudiana, no clearance da glicose em ratos}

\begin{abstract}
Resumo
Stevia rebaudiana, uma planta da América do Sul usada como adoçante natural, parece exercer efeitos benéficos para a saúde humana, incluindo ação anti-hipertensiva e anti-hiperglicêmica. No presente trabalho objetivamos avaliar a excreção renal do esteviol, uma aglicona extraída das folhas de S. rebaudiana, e elucidar a participação deste composto na excreção renal de glicose em ratos, o qual foi sugerido agir no sistema de transporte tubular renal $\mathrm{Na}^{+}$-glicose. $\mathrm{O}$ esteviol foi obtido por hidrólise enzimática com pectinase. Foram usados 30 ratos Wistar machos e pesando $345 \mathrm{~g}$. Após um período controle, o esteviol foi infundido iv em três doses $\left(0,5,1,0\right.$ e 3,0 $\left.\mathrm{mg} \cdot \mathrm{kg}^{-1} / \mathrm{h}\right)$ de acordo com técnicas clássicas de clearance. Durante os experimentos não houve alterações significantes no clearance da inulina $\left(\mathrm{C}_{\mathrm{in}}\right)$ e do ácido-aminohipúrico $\left(\mathrm{C}_{\mathrm{PAH}}\right)$. A administração de esteviol resultou em um aumento estatisticamente significante na excreção fracional de sódio $\left(\mathrm{FeNa}^{+}\right)$e potássio $\left(\mathrm{FeK}^{+}\right)$, no fluxo urinário como porcentagem da taxa de filtração glomerular (V/GFR) e do clearance de glicose $\left(\mathrm{C}_{\mathrm{G}}\right)$ quando comparados aos animais controles, embora estes efeitos estivessem ausentes na dose de $0,5 \mathrm{mg} \cdot \mathrm{kg}^{-1} / \mathrm{h}$. O clearance de esteviol $\left(\mathrm{C}_{\mathrm{S}}\right)$ foi maior que o $\mathrm{C}_{\text {in }}$ e menor que o $\mathrm{C}_{\mathrm{PAH}} \mathrm{em}$ todas as doses usadas nos experimentos. Os dados sugerem a secreção de esteviol pelo epitélio tubular renal, causando diurese, natriurese, caliurese e uma redução na reabsorção tubular renal de excreção de glicose.
\end{abstract}

Palavras-chave: função renal, Steviare baudiana, steviol, excreção renal de glicose.

\section{Introduction}

Stevia rebaudiana Bertoni is one of the 154 members of the genus Stevia and a herb native to South America. The leaves of the shrub contain specific glycosides, which produce a sweet flavour but have no caloric value and are about 30-45 times as sweet as sucrose. For centuries, this herbal sweetener has been used by native Guarani Indians to counteract the bitter flavor of various plant-based medicines and beverages. Many countries have shown interest in its cultivation, and research activities have been initiated. The leaves contain a complex 
mixture of natural sweet diterpene glycosides: stevioside (4-13\% dry weight), steviolbioside (trace), rebaudiosides A (2-4\%), B (trace), C (1-2\%), D (trace), E (trace) and dulcoside A (0.4-0.7\%) (Kinghorn and Soejarto, 1991).

Stevioside is the predominant sweetening component and contains three glucose molecules and steviol, a diterpenic carboxylic alcohol (Kinghorn and Soejarto, 1991). Stevioside has been reported to have acute antihyperglycemic and blood pressure-lowering effects. Curi et al., (1986) observed that extracts of $S$. rebaudiana leaves significantly decreased plasma glucose levels in normal adult humans and Raskovic et al., (2004) that blood glucose levels in mice treated with $S$. rebaudiana and stevioside were lower compared with control treated physiological solution. Pure stevioside causes both bradycardia and hypotension, in humans and rats (Melis, 1992; Schmandke, 2004). In addition, it is able to induce a discrete shortening of the duration of electrical systole, suggesting a positive inotropic effect (Boeckh and Humboldt, 1981). A slight hypotensive effect was also noted in human subjects treated with a $S$. rebaudiana tea administered daily for 30 days (Boeckh, 1992).

We have shown that stevioside induces hypotension, diuresis, natriuresis and kaliuresis (Melis et al., 1986) and a fall in renal tubular reabsorption of glucose in rats (Melis, 1992). These effects are probably dependent on prostaglandin activity (Melis and Sainati, 1991a). Stevioside might be a calcium antagonist as is the case for verapamil (Melis and Sainati, 1991b) and thus could change mean arterial pressure and renal function. $S$. rebaudiana extract, in doses higher than that used for sweetening purposes, is a vasodilator agent, causing hypotension, diuresis and natriuresis in rats (Melis, 1995). On the basis of the data, stevioside and S. rebaudiana extracts could produce changes in renal function parameters. In addition, it is possible that other compounds in $S$. rebaudiana may be involved in the vasodilator response seen in rats treated with a concentrated aqueous extract of this plant (Melis, 1996). On the other hand, steviol, the aglycone of several natural products extracted from the leaves of $S$. rebaudiana, is a diuretic agent without hypotensive activity (Melis, 1997), but has been the subject of relatively few investigations.

The present study employed clearance methodology to evaluate the renal excretion of steviol and clarify the actual participation of this compound on the renal excretion of the same substances in rats. These data may contribute to a better understanding of the effect of steviol on renal function.

\section{Material and Methods}

Plant material was collected from its natural habitat near Amambaí (Paraná, Brazil). The plant was authenticated and a voucher specimen has been deposited in the herbarium of the Department of Botany (FFCLRP), at the University of São Paulo, Brazil.
The total aqueous extract of $S$. rebaudiana leaves was prepared by extraction with hot water. Dried leaves $(100 \mathrm{~g})$ were suspended in $1000 \mathrm{~mL}$ of hot water $\left(100^{\circ} \mathrm{C}\right)$. After 30 minutes, the suspension was filtered through several layers of cheesecloth, and the filtrate used for the preparation of the compounds. Stevioside was isolated from a 1-butanol-soluble extract of $S$. rebaudiana by absorption column chromatography (Kinghorn and Soejarto, 1991). Steviol (molecular weight $=804.80$ ) was obtained by enzymatic hydrolysis of stevioside with pectinase (Pectinol 50 L, Corning Biosystems) (Pezzuto et al., 1985).

Thirty normal male Wistar rats with an average weight of $345 \mathrm{~g}$ and with free access to food and water were used. Animals were anesthetised with $30 \mathrm{mg} \cdot \mathrm{kg}^{-1}$ (ip) of sodium pentobarbital, and placed on a heated table, and a tracheotomy was performed. One jugular vein was catheterised for administration of priming doses and sustained infusion of inulin and p-aminohippuric acid (PAH) according to classical clearance measurement techniques (Smith et al., 1945; Fuhr et al, 1955). Isotonic Ringer's solution containing $2 \% \mathrm{PAH}$ and $10 \%$ inulin was infused at the rate of $0.03 \mathrm{~mL} / \mathrm{min}$ throughout the course of the experiment. Steviol was infused iv through another catheterised jugular vein, which was not used during the control period. One carotid artery was cannulated for collection of blood samples. A catheter was introduced into the urinary bladder for timed urine collection. The animals were distributed in three groups of ten animals each; according to the priming and infusion doses of $0.5,1.0$ and $3.0 \mathrm{mg} \cdot \mathrm{kg}^{-1} / \mathrm{h}$ verified by curve dose-response. The experiments were divided into two periods of 30 minutes each, one a control and the other a period of infusion of different steviol concentrations. In the control and steviol infusion periods, the animals received a similar perfused volume per $\mathrm{g}$ of body weight $\left(0.5,1.0\right.$ and $\left.3.0 \mathrm{mg} \cdot \mathrm{kg}^{-1} / \mathrm{h}\right)$

Inulin concentration in plasma and urine was determined by the anthrone method (Fuhr et al., 1995). Plasma and urinary PAH concentrations were measured by colorimetric (Smith et al., 1945). The sodium and potassium concentrations in urine and plasma were determined through a Klina flame photometer (Beckman Instruments). Glucose determinations in plasma and urine were obtained by colorimetric estimations by anthrone reagent (Metiver and Viana, 1979). Steviol concentration in plasma and urine was determined by chromatography (Kinghorn et al., 1982). The Tukey test was used for statistical analysis of the data, and the results are presented as the Means \pm SEM, with the critical level of significance set at $\mathrm{P}<0.05$.

\section{Results}

Table 1 summarises the results in rats of the measurements of clearances of a number of substances in control and steviol-treated rats at three doses $(0.5,1.0$ and $\left.3.0 \mathrm{mg} \cdot \mathrm{kg}^{-1} / \mathrm{h}\right)$. 
No significant differences were detected in inulin clearance $\left(\mathrm{C}_{\mathrm{in}}\right)$ or p-aminohippuric acid clearance $\left(\mathrm{C}_{\mathrm{PAH}}\right)$, between the periods ( $\mathrm{C}$ and $\mathrm{S}$ ), at any concentration of steviol tested. The mean value of the steviol clearance $\left(\mathrm{C}_{\mathrm{S}}\right)$, at all doses employed, is higher than the $\mathrm{C}_{\text {in }}$ and lower than the $\mathrm{C}_{\mathrm{PAH}}$. It can be seen that steviol at all doses employed, except the lowest, induced a statistically significant increase in glucose clearance $\left(\mathrm{C}_{\mathrm{G}}\right)$ when compared to controls and exhibited a dose-dependent effect. Thus, steviol produces a fall in renal tubular reabsorption of glucose.

There was no effect of steviol on $\mathrm{FeNa}^{+}$and $\mathrm{FeK}^{+}$at a dose of $0.5 \mathrm{mg} \cdot \mathrm{kg}^{-1} / \mathrm{h}$. On the other hand, $\mathrm{FeNa}^{+}$and $\mathrm{FeK}^{+}$increased significantly during steviol infusions (1.0 and $3.0 \mathrm{mg} \cdot \mathrm{kg}^{-1} / \mathrm{h}$ ), showing that steviol increases solute excretion and that this effect is dissociated from changes in the inulin clearance $\left(\mathrm{C}_{\mathrm{in}}\right)$.

\section{Discussion}

The p-aminohippuric acid clearance $\left(\mathrm{C}_{\mathrm{PAH}}\right)$ values, on estimation of renal plasma flow and glomerular filtration rate measured by inulin clearance $\left(\mathrm{C}_{\mathrm{in}}\right)$, did not change in our experiments (Table 1) at any concentration of steviol tested. These data taken together suggest that steviol did not affect the renal hemodynamic. On the other hand, we have shown that stevioside induces systemic and renal vasodilatation, causing hypotension, diuresis and natriuresis per $\mathrm{mL}$ of glomerular filtration rate, which are probably dependent on prostaglandin activity (Melis and Sainati, 1991a). In addition stevioside acts on mean arterial pressure and renal function as a calcium antagonist, as is the case for verapamil (Melis and Sainati, 1991a; Melis, 1992).
It can be seen (Table 1) that steviol at all doses employed, except the lowest, induced a statistically significant increase in glucose clearance $\left(\mathrm{C}_{\mathrm{G}}\right)$ when compared to controls and exhibited a dose-dependent effect. These data are in agreement with previous evidence that stevioside and other $S$. rebaudiana natural products exert an inhibitory effect on monosaccharide transport in the intact rat liver, as is the case for phlorizin and phloretin in the renal tubules (Ishii et al., 1987). This effect presumably occurs at the level of the cell membrane inhibiting the glucose transport system.

The precise mechanism by which steviol affects sodium and potassium transport is not known (Melis, 1997). The proximal convoluted tubule normally reabsorbs $90 \%$ of filtered glucose coupled with sodium and the remaining $10 \%$ is reabsorbed by more distal nephron segments (Lang, 1986). The fact that sodium excretion increased following steviol infusion, in spite of an unchanged glomerular filtration rate, may be explained by inhibition of the glucose reabsorption in the proximal tubules. In more distal nephron segments, changes in salt transport may be elicited by this inhibitory mechanism of the glucose carrier and by the salt load. Nevertheless, it is speculative that the observed effects in the present experiments are due only to the inhibition of glucose reabsorption on the renal tubules. Moreover, steviol may act directly on another step of the mechanism of tubular sodium reabsorption in the present experiments. Another possibility was the osmotic diuresis provoked by the increase of steviol concentrations in renal tubules, increasing $\mathrm{FeNa}^{+}$. Therefore, the model used in the present study is not suitable for discriminating between the direct or indirect effects on renal sodium reabsorption in the distal tubule.

Table 1. Effect of infusion of steviol $\left(0.5,1.0\right.$ and $\left.3.0 \mathrm{mg} . \mathrm{kg}^{-1} / \mathrm{h}\right)$ on clearance of different substances in rats

\begin{tabular}{|c|c|c|c|c|c|c|}
\hline $\begin{array}{c}\text { Dose and } \\
\text { time period } \\
\left(\mathrm{mg} \cdot \mathrm{kg}^{-1} / \mathrm{h}\right)\end{array}$ & $\begin{array}{c}\text { Inulin } \\
\text { clearance } \\
\left(\mathrm{mL} / \mathrm{min}_{\mathrm{k}} \mathrm{kg}^{-1}\right)\end{array}$ & $\begin{array}{l}\text { PAH clearance } \\
\left(\mathrm{mL} / \mathrm{min} \mathrm{kg}^{-1}\right)\end{array}$ & $\begin{array}{c}\text { Steviol } \\
\text { clearance } \\
\left(\mathrm{mL} / \mathrm{min} \mathrm{kg}^{-1}\right)\end{array}$ & $\begin{array}{c}\text { Glucose } \\
\text { clearance } \\
\left(\mathrm{mL} / \mathrm{min} \mathrm{kg}^{-1}\right)\end{array}$ & $\begin{array}{c}\text { Fractional } \\
\text { urinary sodium } \\
\text { excretion } \\
(\%)\end{array}$ & $\begin{array}{c}\text { Fractional } \\
\text { urinary sodium } \\
\text { excretion }(\%)\end{array}$ \\
\hline 0.5 & - & - & - & - & - & - \\
\hline (C) & $5.96 \pm 0.85$ & $16.44 \pm 2.45$ & 0.0 & 0.0 & $0.75 \pm 0.06$ & $23 \pm 3.20$ \\
\hline (S) & $6.02 \pm 0.44$ & $18.00 \pm 0.04$ & $6.96 \pm 1.02 * *$ & 0.0 & $0.82 \pm 0.04$ & $24 \pm 3.04$ \\
\hline $\mathrm{n}$ & 10 & 10 & 10 & 10 & 10 & 10 \\
\hline 1.0 & - & - & - & - & - & - \\
\hline (C) & $6.33 \pm 0.35$ & $18.91 \pm 3.80$ & 0.0 & 0.0 & $0.48 \pm 0.11$ & $23.7 \pm 5.2$ \\
\hline (S) & $6.29 \pm 0.71$ & $15.33 \pm 3.10$ & $8.42 \pm 1.04 * *$ & $1.25 \pm 1.31 * *$ & $1.62 \pm 0.55^{* *}$ & $69.8 \pm 4.3^{* *}$ \\
\hline $\mathrm{n}$ & 10 & 10 & 10 & 10 & 10 & 10 \\
\hline 3.0 & - & - & - & - & - & - \\
\hline (C) & $6.55 \pm 0.83$ & $17.39 \pm 4.33$ & 0.0 & 0.0 & $0.64 \pm 0.09$ & $24.7 \pm 4.36$ \\
\hline (S) & $6.23 \pm 0.44$ & $17.68 \pm 3.29$ & $9.36 \pm 1.41 * *$ & $1.81 \pm 1.69 * *$ & $0.83 \pm 0.15^{* *}$ & $72.9 \pm 5.25^{* *}$ \\
\hline $\mathrm{n}$ & 10 & 10 & 10 & 10 & 10 & 10 \\
\hline
\end{tabular}

Abbreviations: C, control period; S, steviol period; n, number of animals. Significant relative to control values (C) (Tukey test): ** $\mathrm{p}<0.01$. 
Percent fraction potassium excretion $\left(\mathrm{FeK}^{+}\right)$increased after treatment with steviol in all doses employed, except the lowest. These results may be interpreted as follows: the increase in $\mathrm{FeNa}^{+}$after steviol administration indicates elevated sodium concentrations and water travelling in the direction of the distal tubule. This promotes a sodium-potassium exchange, with potassium being extruded and sodium being reabsorbed by the peritubular membrane of the distal tubule. These results agree with data obtained by others in experimental situations involving elevated sodium concentrations (Malnic et al., 1964; Engbretson and Stoner, 1987).

Another point that deserves to be mentioned is the fact that the mean value of steviol clearance $\left(\mathrm{C}_{\mathrm{s}}\right)$, at all doses employed, is higher than the $\mathrm{C}_{\mathrm{in}}$ and lower than the $\mathrm{C}_{\mathrm{PAH}}$ (Table 1). Renal excretion of PAH is the result of glomerular filtration and tubular secretion, although there is a small amount of tubular reabsorption. Also, some PAH may be protein-bound and/or metabolised. It seems possible that at least part of the excretion of steviol in the urine is due to a secretory mechanism at the level of the renal tubular epithelium.

Acknowledgements - We are grateful to CNPq for financial support.

\section{References}

BOECKH, EMA. and HUMBOLDT, G., 1981. Efeitos cardiovasculatórios do extrato aquoso total da Stevia rebaudiana em indivíduos normais e do esteviosideo em ratos. Ciência e Cultura, vol. 32, p. 208-210.

BOECKH, EMA., 1992. Pharmacological drial of a concentrated crude extract of Stevia rebaudiana Bertoni in healthy volunteers. Arquivos de Biologia e Tecnologia, vol. 35, p. 299-314.

CURI, R., ALVAREZ, M., BAZOTTE, RB., BOTION, LM., GODOY, JL. and BRACHT, A., 1986. Effect of Stevia rabaudiana on glucose tolerance in normal adult humans. Brazilian Journal of Medical and Biological Research, vol. 19, no. 6, p. 771-774.

ENGBRETSON, BGJ. and STONER, LC., 1987. Flowdependent potassium secretion by rabbit cortical collecting tubules in vitro. American Journal of Physiology, vol. 235, p. 869-903.

FUHR, J., KACZAMARAZYK, J. and KRUKGEEN, CD., 1995. Eine einfache kolorimetrische method zur Insulinbestimmung fur Nierenclearance-Untersuchungen bei Stoffwechselgesunden und Diabetiken. Kli Wochenschr, vol. 33, p. 720-730.

ISHII, EL., SCHWAB, AJ. and BRACHT, A., 1987. Inhibition of monosaccharide transport in the intact rat liver by stevioside. Biochemical Pharmacology, vol. 36, no. 9, p. 1417-1433.

KINGHORN, AD. and SOEJARTO, DD., 1991. Stevioside. In O'BRIEN, NL. and GELARDI, RC. (Eds.). Alternative Sweetners. New York; Basel; Hong Kong: Marcell Dekker Inc. p. $157-171$

KINGHORN, AD., NANAYAKKARA, NPD., SOEJARTO, DD., MEDON, PJ. and KAMATH, S., 1982. Potential sweetening agents of plant origin. I. Purification of Stevia rebaudiana sweet constituents by dropled counter-current chromatography. Journal of Chromatography, vol. 237, p. 478-483.

KINGHORN, AD., 1992. Food ingredient safety review: Stevia rebaudiana leaves. USA: Herb Research Foundation.

LANG, F., MESSNER, G. and REHWALD, W., 1986. Electrophysiology of sodium coupled transport in proximal renal tubule. American Journal of Physiology, vol. 250, p. 953-962.

MELIS, MS., SAINATI, AR. and MACIEL, RE., 1986. Effects of two concentrations of stevioside on renal function and mean arterial pressure in rats. IRCS Medical Science, vol. 14, no. 10, p. $973-974$

MALNIC, G., KLOSE, RM. and GIEBISCH, G., 1964. Micropuncture study of renal potassium excretion in the rat. American Journal of Physiology, vol. 206, p. 647-686.

MELIS, MS. \& SAINATI, AR., 1991a. Participation of prostaglandins in the effect of stevioside on renal function and arterial pressure in rats. Brazilian Journal of Medical and Biological Research, vol. 24, no. 12, p. 1269-1276.

1991b. Effect of calcium and verapamil on renal function of rats during treatment with stevioside. Journal of Ethnopharmacology, vol. 33, p. 257-262.

MELIS, MS., 1992. Renal excretion of stevioside in rats. Journal of Natural Products, vol. 55, n. 5, p. 688-690.

1995. Chronic administration of aqueous extract of Stevia rebaudiana in rats: renal effects. Journal of Ethnopharmacology, vol. 47, p. 129-134.

1996. A crude of Stevia rebaudiana increases the renal plasma flow of normal and hypertensive rats. Brazilian Journal of Medical and Biological Research, vol. 29, no. 5, p. 669-675.

1997. Effects of Steviol on renal function and mean arterial pressure in rats. Phytomedicine, vol. 3, n. 4, p. $349-352$

METIVER, J. and VIANA, AM., 1979. Determination of microgram quantities of stevioside from leaves of Stevia rebaudiana Bert. by two-dimensional thin layer chromatography. Journal Experimental Biology, vol. 30, p. 805-809.

PEZZUTO, JM., COMPADRE, CM., SWANSON, SM., NANAYAKKARA, NPD. and KINGHORN, AD., 1985. Metabolically activated steviol, the aglycone of the stevioside is mutagenic. Proceedings of the Academy of Natural Science, vol. 82 , no. 8, p. 2478-2482.

RASKOVIC, A., GAVRILOVIC, M. and SABO, J., 2004. Glucose concentration in the blood of intact and alloxan-treated mice after pretreatment with commercial preparations of Stevia rebaudiana (Bertoni). European Journal of Drug Metabolism and Pharmacokinetics, vol. 29 , n. 2, p. 87-90.

SCHMANDKE, H., 2004. Sweet-tasting steviol glycoside derivatives with antihyperglycaemic and antihypertensive effects. Ernahrungs-Umschau, vol. 51, no. 11, p. 455-462.

SMITH, HW., FINKELSTEIN, N., ALIMINOSA, L., CRAWFORD, B. and GRABER, M., 1945. The renal clearances of substitute hippuric acid derivates and other aromatic acids in dog and man. Journal of Clinical Investigation, vol. 24, p. $338-340$

VON SCHMELING, GA., 1967. Edulcorante natural não calórico. Boletim do Sanatório São Lucas, vol. 94, p. 67-68. 